OPEN ACCESS

Edited by:

Olga Matos,

New University of Lisbon, Portugal

Reviewed by:

Andrew Harold Limper,

Mayo Clinic, United States

Jay K. Kolls,

Tulane Medical Center, United States

*Correspondence:

Melanie T. Cushion

cushiomt@ucmail.uc.edu

Specialty section:

This article was submitted to

Infectious Diseases,

a section of the journal

Frontiers in Microbiology

Received: 16 March 2021

Accepted: 16 April 2021

Published: 20 May 2021

Citation:

Cushion MT, Tisdale-Macioce N

Sayson SG and Porollo A (2021) The Persistent Challenge of Pneumocystis Growth Outside the Mammalian Lung:

Past and Future Approaches.

Front. Microbiol. 12:681474.

doi: 10.3389/fmicb.2021.681474

\section{The Persistent Challenge of} Pneumocystis Growth Outside the Mammalian Lung: Past and Future Approaches

\author{
Melanie T. Cushion ${ }^{1,2 *}$, Nikeya Tisdale-Macioce ${ }^{1,2}$, Steven G. Sayson ${ }^{1,2}$ and \\ Aleksey Porollo ${ }^{3,4}$
}

'Department of Internal Medicine, University of Cincinnati College of Medicine, Cincinnati, OH, United States, ${ }^{2}$ Medical Research Service, Cincinnati Veterans Affairs Medical Center, Cincinnati, OH, United States, ${ }^{3}$ Department of Pediatrics, University of Cincinnati College of Medicine, Cincinnati, OH, United States, ${ }^{4}$ Center for Autoimmune Genomics and Etiology, Division of Biomedical Informatics, Cincinnati Children's Hospital Medical Center, Cincinnati, $\mathrm{OH}$, United States

The pathogenic fungi in the genus, Pneumocystis, have eluded attempts to continuously grow them in an ex vivo cultivation system. New data from transcriptomic and genomic sequencing studies have identified a myriad of absent metabolic pathways, helping to define their host obligate nature. These nutrients, factors, and co-factors are acquired from their mammalian host and provide clues to further supplementation of existing media formulations. Likewise, a new appreciation of the pivotal role for the sexual cycle in the survival and dissemination of the infection suggests that Pneumocystis species are obligated to undergo mating and sexual reproduction in their life cycle with a questionable role for an asexual cycle. The lack of ascus formation in any previous cultivation attempts may explain the failure to identify a sustainable system. Many characteristics of these ascomycetes suggest a biotrophic existence within the lungs of the mammalian hosts. In the present review, previous attempts at growing these fungi ex vivo are summarized. The significance of their life cycle is considered, and a list of potential supplements based on the genomic and transcriptomic studies is presented. State of the art technologies such as metabolomics, organoids, lung-on-a chip, and air lift cultures are discussed as potential growth systems.

Keywords: Pneumocystis species, fungal pathogens, in vitro growth, Pneumocystis pneumonia, fastidious

\section{INTRODUCTION}

Fungi in the genus, Pneumocystis, are host-obligate pathogens that can cause lethal pneumonia in mammals with impaired immune function, including humans. During the previous decades, HIV+ patients have made up the largest proportion of hospitalized cases of Pneumocystis pneumonia within the United States. However, recent studies have shown that malignancies now are the most prevalent host factor for hospitalizations with Pneumocystis jirovecii pneumonia accounting for $46 \%$ of cases in the United States compared to $17.8 \%$ with HIV+ as the underlying illness (Kanj et al., 2021). Moreover, a recent assessment of pneumonias in children 1-59 months in African and Asian countries revealed that $P$. jirovecii was a significant cause of infection, especially in children younger than 1 year of age (The Pneumonia Etiology Research for Child Health (Perch) study group, 2019). The increase in susceptible populations and the dearth of treatment options, signal a desperate need for new therapies. The search for new treatments for this fungal infection, 
as well as other aspects of investigation, have been hindered by the lack of a continuous in vitro cultivation system.

Such an ex vivo cultivation system remains elusive since the identification of these fastidious organisms over a century ago. As a result, the scientific community lacks a genetic system to explore gene function by knock- out/in technology; a drug screening assay that can discern pneumocysticidal vs static outcomes and one that can be used to screen the drug-induced phenotype of the infecting Pneumocystis species; as well as epidemiological studies that can identify drug resistant genotypes and track them throughout populations.

The origin of the Pneumocystis species was fraught with problems. It was first identified in 1909 as part of the life cycle of the parasite, Trypanosoma cruzi, in animals co-infected with the trypanosomes and Pneumocystis (Redhead et al., 2006). The pursuant attempts at taxonomic classification further exacerbated its valid identity by applying the International Code of Zoological Nomenclature rules for naming these microbes which resulted in acceptance of "Pneumocystis" as a zoonosis and thus one species, Pneumocystis carinii, could infect several mammalian species including humans and rats. The identity of Pneumocystis as fungal or protozoan was also controversial. Its true nature as a fungal pathogen was not fully resolved until well into the 21st century. In 2006, invalid names were eliminated, and the different species of Pneumocystis were validated with typification and named according to the Botanical Code of Nomenclature rules used for fungi (Redhead et al., 2006).

Gene and genome sequencing provided certain confirmation that "Pneumocystis" was a genus comprised of many species and each species was usually associated with a single mammalian host species. Efforts to correctly name the species led to the valid names and descriptions of 5 formally described species to date: Pneumocystis jirovecii which infects humans (Homo sapiens) (Redhead et al., 2006); P. murina which infects mice (Mus musculus) (Keely et al., 2004); P. carinii (Redhead et al., 2006) and $P$. wakefieldiae, that infect rats (Rattus norvegicus) (Cushion et al., 2004); and P. oryctolagi which infects rabbits (Oryctolagus cuniculus) (Dei-Cas et al., 2006).

Such efforts are not purely academic exercises, as understanding of a fungal or protozoan identity could suggest different approaches for cultivation outside the mammalian lung. Indeed, investigators applied techniques associated with the culture of either of these microbes as well as other tissue culture approaches, but none led to the "Holy Grail" of continuous passage and growth. This failure was not surprising considering the general lack of systematic assessments in the various trials and more importantly, the lack of understanding of the reduced metabolic capabilities of these host-obligate fungi.

Although little progress has been made in this area, strides in understanding the role of the life cycle and new technology provide avenues for further progress towards this goal. In this review, the previous attempts to cultivate these fungi will be summarized; the life cycle and implications on growth outside the lung will be discussed; the lack of metabolic capacity as revealed by genome sequencing will be examined; and novel, potential in vitro approaches will be presented.

\section{PREVIOUS CULTIVATION ATTEMPTS}

Review of the published attempts to culture rodent-derived and human-derived Pneumocystis on cell monolayers and in cell free media clearly reveal the lack of continuous passage and the abbreviated growth in primary (host-derived organisms that were not passaged) culture (Tables 1, 2). The assessment of "growth" varied widely, including microscopic enumeration with various tinctorial staining methods, ATP content, total DNA quantification and quantitative PCR methods to targeted genes, but in toto, there has been no system that has emerged as a reproducible method that has stood the test of time using any quantification technique. The failure of various laboratories when trying to replicate published methods has not been well documented in the literature as negative studies are not given priority in journals. Two studies garnered high interest; results reported by Merali et al. (1999) using Transwell inserts and Schildgen et al. (2014) using a novel cell line and an air-liquid interface system with $\mathrm{CuFi}-8$ cells. Both reports were discounted when other laboratories conducted serious attempts at replication and were unsuccessful (Liu et al., 2018). Such publications are quite valuable to the community, avoiding lost time and expensive reagents. The most practical test would be the widespread adoption of a successful technique by many laboratories, which has clearly not occurred post-publication of any report.

Mostly guided by requirements of other fungi or pathogens, culture attempts have relied on cell monolayers flooded by liquid media or cell-free media to which the Pneumocystis species (spp.) are directly inoculated. Neither environment adequately mimics the unique location in the lung where these fungi grow in the "hypophase" of the alveoli which is a thin continuous layer of about $200 \mathrm{~nm}$ that likely covers the entirety of the alveolar surface (Fehrenbach, 2001). The composition of the hypophase includes pulmonary surfactant which is regulated by $\mathrm{pH}$ and $\mathrm{Ca}^{2+}$ proximally and provides low surface tension. The Type II pneumocyte or Alveolar Epithelial Cell Type 2 (AEC2) secretes a myriad of other factors including epidermal growth factor, VEGF, adhesion molecules, lipids (especially dipalmitoyl phosphatidylcholines) entactin, laminin, fibronectin, and proteoglycans. The presence of this liquid lining layer means the alveolar epithelial cells (AEC1 and AEC2) are not directly exposed to air (Knudsen and Ochs, 2018). Most of these factors have been added to one in vitro system or another, without success.

\section{THE PROPOSED LIFE CYCLE}

A better understanding of the life cycle and the host obligate nature of these microscopic fungi are essential to the Pneumocystis ouroborous that may include an asexual cycle, a sexual phase, an immune- debilitated mammalian host and dissemination of the infection. First guided by images provided by light-, fluorescent-, and transmission electron microscopy, proposed life cycles included asexual replication via binary fission; asexual and sexual replication leading to the production of asci (once referred to as "cysts"); exit of the asci from the 
TABLE 1 | In vitro culture of Pneumocystis species with primary and cell lines.

\begin{tabular}{|c|c|c|c|c|c|}
\hline $\begin{array}{l}\text { References/Year of } \\
\text { publication }\end{array}$ & Source of inoculum & $\begin{array}{l}\text { Cell type/lines } \\
\text { supporting "growth"a } \\
\text { Medium/temperature }\end{array}$ & $\begin{array}{l}\text { Quantification } \\
\text { method }\end{array}$ & $\begin{array}{l}\text { Maximal reported } \\
\text { growth in one } \\
\text { cycle/time of peak } \\
\text { growth }\end{array}$ & $\begin{array}{l}\text { Other cell lines } \\
\text { reported as } \\
\text { non-supportive of } \\
\text { growth }\end{array}$ \\
\hline $\begin{array}{l}\text { Pifer et al. (1977) } \\
1977\end{array}$ & $\begin{array}{l}\text { P. carinii from } \\
\text { immunosuppressed } \\
\text { Sprague-Dawley rats lung } \\
\text { wash } \\
\text { P. jirovecii }\end{array}$ & $\begin{array}{l}\text { Chicken embryonic } \\
\text { epithelial lung cells (CEL); } \\
\text { M99 with } 10 \% \text { FBS or M99 } \\
\text { with } 2 \% \text { FBS, } 35^{\circ} \mathrm{C} \text { with } \\
5 \% \mathrm{CO}_{2}\end{array}$ & $\begin{array}{l}\text { Enumeration of asci, } \\
\text { toluidine blue O stain } \\
\text { (TBO) }\end{array}$ & $\begin{array}{l}3 \text { to } 10 \text {-fold for } \\
\text { P. carinii; } 24-48 \mathrm{~h} \text {. } \\
\text { 10-fold }{ }^{*} \text { for P. jirovecii; } \\
24-48 \mathrm{~h} \text {. }\end{array}$ & $\begin{array}{l}\text { AV3, WI-38, L cells, rat } \\
\text { lung, secondary } \\
\text { chicken embryo } \\
\text { fibroblasts, owl monkey } \\
\text { kidney, baby hamster } \\
\text { kidney, Chang liver cells }\end{array}$ \\
\hline $\begin{array}{l}\text { Pifer et al. (1978) } \\
1978\end{array}$ & $\begin{array}{l}\text { P. carinii from } \\
\text { immunosuppressed } \\
\text { Sprague-Dawley rat lungs } \\
\text { shaken in PBS }\end{array}$ & $\begin{array}{l}\text { Vero cell line; MEM with } 2 \% \\
\text { FBS, } 35^{\circ} \mathrm{C} \text { with } 5 \% \mathrm{CO}_{2}\end{array}$ & $\begin{array}{l}\text { Enumeration of asci, } \\
\text { TBO }\end{array}$ & 11-fold; 72 hours & ND \\
\hline $\begin{array}{l}\text { Latorre et al. (1977) } \\
1977\end{array}$ & $\begin{array}{l}\text { P. carinii from } \\
\text { immunosuppressed } \\
\text { Sprague-Dawley rat lung } \\
\text { homogenate }\end{array}$ & $\begin{array}{l}\text { Vero, Chang liver, MRC- } 5 \\
\text { cell lines; Eagle's Essential } \\
\text { medium with } 10 \% \text { fetal calf } \\
\text { serum; } 37^{\circ} \mathrm{C} \text { with no } \mathrm{CO}_{2}\end{array}$ & $\begin{array}{l}\text { Visual estimation of the } \\
\text { density of floating } \\
\text { clusters of organisms }\end{array}$ & ND & LLC-MK-2, FL, McCoy \\
\hline $\begin{array}{l}\text { Bartlett et al. (1979) } \\
1979\end{array}$ & $\begin{array}{l}\text { P. carinii from } \\
\text { immunosuppressed } \\
\text { Sprague-Dawley rat lung } \\
\text { homogenate } \\
\text { P. jirovecii }\end{array}$ & $\begin{array}{l}\text { WI-38 and MRC- } 5 \text { cell } \\
\text { lines; Eagle's essential } \\
\text { medium with } 10 \% \text { fetal calf } \\
\text { serum; } 35^{\circ} \mathrm{C} \text { with no } \mathrm{CO}_{2}\end{array}$ & $\begin{array}{l}\text { Enumeration of } \\
\text { Giemsa-stained } \\
\text { "trophozoites" }\end{array}$ & $\begin{array}{l}\text { 13-fold; } 4 \text {-8 days for } \\
\text { P. carinii on both cell } \\
\text { lines } \\
\text { No growth with } \\
\text { P. jirovecii }\end{array}$ & ND \\
\hline $\begin{array}{l}\text { Cushion et al. (Cushion } \\
\text { and Walzer, 1984; } \\
\text { Cushion et al., 1985) } \\
\text { 1984/1985 }\end{array}$ & $\begin{array}{l}\text { P. carinii from } \\
\text { immunosuppressed } \\
\text { Sprague-Dawley rat lung } \\
\text { homogenate } \\
P . \text { jirovecii from } \\
\text { bronchoalveolar lavage and } \\
\text { tissue (BALF) }\end{array}$ & $\begin{array}{l}\text { A549 cell line } \\
\text { Dulbecco's modified Eagle } \\
\text { medium (DMEM) with } 10 \% \\
\text { inactivated FBS at } 37^{\circ} \mathrm{C} \\
\text { with } 5 \% \mathrm{CO}_{2} \\
\text { WI-38 VA } 13 \text { Subline } 2 \mathrm{RA} \\
\mathrm{HMEM}, 25 \mathrm{mM} \text { HEPES, } \\
10 \% \mathrm{FBS}, 2 \mathrm{X} \text { MEM vitamin } \\
\text { solution, } 1 \mathrm{X} \text { non-essential } \\
\text { amino acid solution } 37^{\circ} \mathrm{C} \\
\text { with } 5 \% \mathrm{CO}_{2}\end{array}$ & $\begin{array}{l}\text { Rapid Giemsa } \\
\text { (Diff-Quik }{ }^{T M} \text { ) for } \\
\text { enumeration of } \\
\text { nuclei/ml; cresyl echt } \\
\text { violet (CEV) for asci }\end{array}$ & $\begin{array}{l}\text { (A549) 10-fold; Day 7; } \\
\text { (WI-38 VA13 Subline } \\
\text { 2RA) 20-fold. } \\
\text { (A549) 10-fold; Day } 14 \\
\text { with } 1 \text { of } 10 \text { isolates. } \\
\text { ND for WI-38 VA13 } \\
\text { subline 2RA }\end{array}$ & $\begin{array}{l}\text { WI-38, L2, 4/4 RM4, } \\
\text { RFL-6, Hep-2 }\end{array}$ \\
\hline $\begin{array}{l}\text { Smith and Bartlett } \\
(1984) \\
1984\end{array}$ & $\begin{array}{l}\text { P. carinii from } \\
\text { immunosuppressed } \\
\text { Sprague-Dawley rat lung } \\
\text { homogenate }\end{array}$ & $\begin{array}{l}\text { Walker (LLC-WRC 256) } \\
\text { MDBK } \\
\text { HeLa } \\
\text { LU-1 } \\
\text { MCF-7 }\end{array}$ & $\begin{array}{l}\text { Enumeration of } \\
\text { Giemsa-stained } \\
\text { "trophozoites" }\end{array}$ & $\mathrm{NG}^{* * *}$ & ND \\
\hline $\begin{array}{l}\text { Armstrong and } \\
\text { Richards } \\
1989\end{array}$ & $\begin{array}{l}\text { P. carinii from } \\
\text { immunosuppressed } \\
\text { Sprague-Dawley rats lung } \\
\text { wash }\end{array}$ & $\begin{array}{l}\text { Mv } 1 \text { Lu cell line } \\
\text { HEPES buffered Eagle's } \\
\text { MEM with Earl's salts with } \\
1 \mathrm{X} \text { non-essential amino } \\
\text { acids, } 1 \% \text { sodium pyruvate, } \\
1 \% \mathrm{~L} \text {-glutamine, and } 10 \% \\
\text { heat-inactivated FCS; } 37^{\circ} \mathrm{C} \\
\text { with } 5 \% \mathrm{CO}_{2}\end{array}$ & $\begin{array}{l}\text { Giemsa stain for } \\
\text { enumeration of all } \\
\text { stages }\end{array}$ & $\begin{array}{l}\text { 2-6-fold } \\
\text { Days } 4 \text { to } 8\end{array}$ & \\
\hline $\begin{array}{l}\text { Cushion and Walzer } \\
\text { (Cushion, 1989) } \\
1989\end{array}$ & $\begin{array}{l}\text { P. carinii from } \\
\text { immunosuppressed } \\
\text { Sprague-Dawley rat lung } \\
\text { homogenate }\end{array}$ & $\begin{array}{l}\text { Fetal organotypic culture } \\
\text { Lung explant culture } \\
37^{\circ} \mathrm{C}, 5 \% \mathrm{CO}_{2}\end{array}$ & $\begin{array}{l}\text { Rapid Giemsa } \\
\text { (Diff-Quik }{ }^{T M} \text { ) for } \\
\text { enumeration of } \\
\text { nuclei/ml; cresyl echt } \\
\text { violet (CEV) for asci }\end{array}$ & $N G$ & \\
\hline $\begin{array}{l}\text { Bartlett et al. (1992) } \\
1992\end{array}$ & $\begin{array}{l}\text { P. carinii from } \\
\text { immunosuppressed } \\
\text { Sprague-Dawley rat lung } \\
\text { homogenate }\end{array}$ & $\begin{array}{l}\text { Human embryonic lung } \\
\text { cells; } \\
\text { MEM without serum; } 35^{\circ} \mathrm{C} \\
\text { in } 5 \% \mathrm{CO}_{2}\end{array}$ & $\begin{array}{l}\text { Giemsa stain for } \\
\text { enumeration of } \\
\text { "trophozoites: }\end{array}$ & 3-fold; 7 days & \\
\hline
\end{tabular}


TABLE 1 | Continued

\begin{tabular}{|c|c|c|c|c|c|}
\hline $\begin{array}{l}\text { References/Year of } \\
\text { publication }\end{array}$ & Source of inoculum & $\begin{array}{l}\text { Cell type/lines } \\
\text { supporting "growth"a } \\
\text { Medium/temperature }\end{array}$ & $\begin{array}{l}\text { Quantification } \\
\text { method }\end{array}$ & $\begin{array}{l}\text { Maximal reported } \\
\text { growth in one } \\
\text { cycle/time of peak } \\
\text { growth }\end{array}$ & $\begin{array}{l}\text { Other cell lines } \\
\text { reported as } \\
\text { non-supportive of } \\
\text { growth }\end{array}$ \\
\hline $\begin{array}{l}\text { Aliouat et al. (1999) } \\
1999\end{array}$ & $\begin{array}{l}\text { P. carinii from } \\
\text { immunosuppressed rat } \\
\text { lung homogenates }\end{array}$ & $\begin{array}{l}\text { L2 cells; } \\
\text { DMEM } 10 \% \\
\text { heat-inactivated fetal calf } \\
\text { serum; } 37^{\circ} \mathrm{C} \text { with } 5 \% \mathrm{CO}_{2}\end{array}$ & $\begin{array}{l}\text { TBO for asci, RAL555 } \\
\text { for trophozoites and } \\
\text { "filled" asci }\end{array}$ & 2-4-fold & \\
\hline $\begin{array}{l}\text { Cirioni et al. (1997, } \\
\text { 2000) } \\
\text { 1997/2000 }\end{array}$ & P. jirovecii from BALF & $\begin{array}{l}\text { A549 cell line; } \\
\text { DMEM with and without a } \\
\text { serum supplement of } 10 \% \\
\text { FCS; Fe(NO) } 3 \text {; L-glutamine, } \\
\text { HEPES; } 37^{\circ} \mathrm{C} \text { with } 5 \% \mathrm{CO}_{2}\end{array}$ & $\begin{array}{l}\text { Giemsa for } \\
\text { enumeration of } \\
\text { "trophozoites: and } \\
\text { methenamine silver for } \\
\text { asci }\end{array}$ & 3-fold; 72 h. & \\
\hline $\begin{array}{l}\text { Atzori et al. (1998) } \\
1998\end{array}$ & $\begin{array}{l}\text { P. carinii from } \\
\text { immunosuppressed rat } \\
\text { lung homogenate }\end{array}$ & $\begin{array}{l}\mathrm{L} 2 \text {; Dulbecco's modified } \\
\text { Eagle's medium, } 5 \% \mathrm{CO}_{2} \text {, } \\
37^{\circ} \mathrm{C}\end{array}$ & $\begin{array}{l}\text { RAL } 555 \text { (Rapid } \\
\text { Giemsa-like stain) for all } \\
\text { stages except asci; } \\
\text { toluidine blue O for asci }\end{array}$ & 2-4-fold & \\
\hline $\begin{array}{l}\text { Ni and Chen (2001) } \\
2001\end{array}$ & $\begin{array}{l}\text { P. carinii from } \\
\text { immunosuppressed rat } \\
\text { lung homogenates }\end{array}$ & HepG-2 cell line; & $\begin{array}{l}\text { Diff-Quik }{ }^{T M} \text { for } \\
\text { "trophozoites" } \\
\text { Gomorri's methenamine } \\
\text { silver stain for asci }\end{array}$ & 5 days & \\
\hline $\begin{array}{l}\text { Schildgen et al. } \\
2014^{\star \star}\end{array}$ & P. jirovecii from BALF & $\begin{array}{l}\text { CuFi-8 cell line; } \\
\text { Bronchial epithelial cell } \\
\text { basal medium (BEBM) } \\
\text { grown on human placental } \\
\text { collagen in flasks then } \\
\text { transferred to transwells } \\
\text { with Ham's F12K medium; } \\
37^{\circ} \mathrm{C}\end{array}$ & $\begin{array}{l}\text { qPCR targeting the } \\
\text { mitochondrial large } \\
\text { subunit rRNA (mtLSU) } \\
\text { and Major surface } \\
\text { glycoprotein (MSG) }\end{array}$ & $\begin{array}{l}\text { Up to } 3 \log _{10} \text { units for } \\
\text { both targets; } 5 \text { days }\end{array}$ & \\
\hline
\end{tabular}

*Not apparent from the presented data.

${ }^{* *}$ According to the publication by Kovacs et al., this system could not be duplicated (Liu et al., 2018).

${ }^{* * *}$ No Growth.

host; and release of spores ("daughter forms") to initiate infection in a new host. A distillation of these hypotheses and proposed life cycle stages are shown below, Figure 1. Recent studies using molecular technology such as RNA-seq and high throughput sequencing have provided strong evidence for a sexual cycle in the lung with primary homothallism as the mode, but these and other reports have cast doubt whether an asexual cycle is necessary or even operational (Hauser and Cushion, 2018). That the ascus is the agent of transmission was shown by experiments in the mouse model of Pneumocystis infection (Cushion et al., 2010). Treatment with commercially available echinocandins does not eliminate Pneumocystis pneumonia, rather these drugs inhibit the ability of Pneumocystis to produce asci, owing to their inhibition of $\beta-1,3-\mathrm{D}$-glucan biosynthesis. Our laboratory showed that these mice without asci, but with large organism populations that did not produce $-\beta-1,3-\mathrm{D}$-glucan, were unable to transmit the infection. Inoculation of these same organisms into $P$. murina-naive and immunosuppressed mice were able to reconstitute the infection with the re-emergence of asci.

\section{BIOFILM FORMATION}

Formation of biofilms is a strategy used by pathogenic microbes as well as microbes found throughout the environment. Organized microbial communities of fungi and bacteria attach to biotic or abiotic matrices to exchange plasmids, reduce susceptibility to antimicrobial agents and/or host immune responses or to protect members from other environmental stresses. These structures are also used to seed environments by dispersion from the community. Many pathogenic fungi utilize biofilms to survive within the host environment including Candida spp. (Ramage et al., 2001a,b; Mowat et al., 2007), Cryptococcus neoformans (Martinez and Casadevall, 2007), and Aspergillus fumigatus (Mowat et al., 2007). The structure of the Pneumocystis cells with the alveoli of the lung follows the characteristics of a biofilm as they are closely enmeshed, contain exopolymeric components, and spread throughout the lung (Cushion et al., 2009). We showed that P. carinii and P. murina could produce macroscopically visible and reproducible biofilms on inserts composed of hydrophilized PTFE (Biopore-CM from Millipore) and Millicell-HA cellulose (Cushion et al., 2009). These fungi rapidly formed tightly adherent biofilms that were able to maintain ATP levels over 2-3 weeks. Notably, the organisms completely changed morphology in biofilms. Figure 2A shows an organism cluster from an RPMI-1640-based cell-free culture stained with a rapid variant of the WrightGiemsa stain. Note the changes in structure as the biofilm matures (Figures 2B-L). Although all samples were stained with Wright-Giemsa, many structures excluded the dyes and were refractile under light microscopy. 
TABLE 2 | In vitro culture of Pneumocystis species in cell free media.

\begin{tabular}{|c|c|c|c|c|}
\hline $\begin{array}{l}\text { References/Year of } \\
\text { publication }\end{array}$ & Source of inoculum & Medium/temperature & $\begin{array}{l}\text { Quantification } \\
\text { method }\end{array}$ & $\begin{array}{l}\text { Maximal reported } \\
\text { growth in one } \\
\text { cycle/time of peak } \\
\text { growth }\end{array}$ \\
\hline $\begin{array}{l}\text { Pifer et al. (1977) } \\
1977\end{array}$ & $\begin{array}{l}\text { P. carinii from } \\
\text { immunosuppressed } \\
\text { Sprague-Dawley rats } \\
\text { lung wash }\end{array}$ & $\begin{array}{l}\text { Balamuth's egg extract medium } \\
\text { Blair's medium } \\
\text { Chang's medium } \\
\text { Diamond's medium } \\
\text { Newton's medium } \\
\text { NNN medium } \\
\text { Pan's medium } \\
\text { Schaedler's broth } \\
\text { Tobie's medium } \\
\text { All were at } 35^{\circ} \mathrm{C}\end{array}$ & $\begin{array}{l}\text { Enumeration of asci, } \\
\text { toluidine blue O stain }\end{array}$ & $N G^{*}$ \\
\hline $\begin{array}{l}\text { Tegoshi and Yoshida } \\
1989\end{array}$ & $\begin{array}{l}\text { P. murina from nude } \\
\text { mice }\end{array}$ & $\begin{array}{l}\text { L15 or DMEM } \\
10 \% \text { heat-inactivated FBS, } 100 \mu \mathrm{M} \\
\text { 2-mercaptoethanol, } 50 \mu \mathrm{M} \text { bathocuprine } \\
\text { sulphonate; cysteine was added daily (quantity } \\
\text { not specified) } \\
37^{\circ} \mathrm{C}, 5 \% \mathrm{CO}_{2}\end{array}$ & $\begin{array}{l}\text { Enumeration, Giemsa } \\
\text { stain }\end{array}$ & $\begin{array}{l}\text { 4-10 fold; L-15 showed } \\
\text { slightly better results }\end{array}$ \\
\hline \multirow[t]{2}{*}{$\begin{array}{l}\text { Cushion and Ebbets } \\
\text { (1990) } \\
1990\end{array}$} & $\begin{array}{l}\text { P. carinii from } \\
\text { immunosuppressed } \\
\text { Lewis rat lungs }\end{array}$ & $\begin{array}{l}\text { DMEM } \\
\text { Yeast extract-peptone-dextrose (YEPD) broth } \\
\text { and agar } \\
\text { Yeast extract-malt extract (YM) } \\
\text { Brain Heart Infusion broth and agar } \\
\text { Wort broth and agar } \\
\text { Sabourad's broth and agar } \\
\text { Vogel and Johnson agar } \\
\text { Physiological saline, phosphate buffered saline, } \\
\text { Hanks balanced salt solution. } \\
\text { Solid agars tested at } 4.0 \text { and } 7.0 \mathrm{pH} \text {. }\end{array}$ & $\begin{array}{l}\text { Diff-Quick stain for all } \\
\text { life cycle stages }\end{array}$ & $N G$ \\
\hline & & $\begin{array}{l}1 \% \text { neopeptone (wt/vol) with } 0.2 \%(\mathrm{wt} / \mathrm{vol}) \\
\mathrm{N} \text {-acetylglucosamine (NPG) at } \mathrm{pH} 4.0,5 \% \mathrm{CO}_{2} \text {, } \\
37^{\circ} \mathrm{C}^{\star \star}\end{array}$ & & 8-10-fold \\
\hline $\begin{array}{l}\text { Lasbury et al. (1999) } \\
1999\end{array}$ & $\begin{array}{l}\text { P. murina and } P \text {. carinii } \\
\text { from } \\
\text { immunosuppressed } \\
\text { lungs }\end{array}$ & $\begin{array}{l}\text { Medium as above (Merali et al., 1999) in } \\
\text { Biocoat cell culture inserts }\end{array}$ & $\begin{array}{l}\text { Giemsa for } \\
\text { "trophozoites" }\end{array}$ & $\begin{array}{l}\text { 12-fold for P. murina; } \\
\text { 14-fold for P. carinii }\end{array}$ \\
\hline $\begin{array}{l}\text { Sobolewska and } \\
\text { Dzbenski (2009) } \\
2009\end{array}$ & $\begin{array}{l}\text { P. carinii from } \\
\text { immunosuppressed } \\
\text { Wistar rat lungs }\end{array}$ & $\begin{array}{l}\text { MEME with } 10 \% \text { horse serum, } 500 \mu \mathrm{M} \text { twice } \\
\text { per day S-adenosyl-methionine sulfate, } \\
80 \mu \mathrm{g} / \mathrm{ml} \text { of p-aminobenzoic acid, putrescine, } \\
\text { ferric pyrophosphate, } \mathrm{L} \text {-cysteine, } \mathrm{L} \text {-glutamine, } \\
\text { and } \mathrm{N} \text {-acetyl-glucosamine with penicillin and } \\
\text { streptomycin; } 31^{\circ} \mathrm{C} \text {, normal atmosphere } \\
\text { Inoculated in } 0.4 \mu \mathrm{M} \text { pore, collagen coated } \\
\text { Transwells and suspended in the medium } \\
\text { described above }\end{array}$ & $\begin{array}{l}\text { Giemsa and Diff-Quick } \\
\text { for asci; PCR directed } \\
\text { to the mtLSUrRNA }\end{array}$ & $\begin{array}{l}257 \text {-fold increase in } \\
\text { asci; } 286 \text {-fold with } \\
\text { RT-PCR }\end{array}$ \\
\hline
\end{tabular}


TABLE 2 | Continued

\begin{tabular}{|c|c|c|c|c|}
\hline $\begin{array}{l}\text { References/Year of } \\
\text { publication }\end{array}$ & Source of inoculum & Medium/temperature & $\begin{array}{l}\text { Quantification } \\
\text { method }\end{array}$ & $\begin{array}{l}\text { Maximal reported } \\
\text { growth in one } \\
\text { cycle/time of peak } \\
\text { growth }\end{array}$ \\
\hline Cushion et al. (2009) & $\begin{array}{l}\text { P. carinii from } \\
\text { immunosuppressed rat } \\
\text { lungs } \\
\text { P. murina from } \\
\text { immunosuppressed } \\
\text { mouse lungs } \\
\text { Both from } \\
\text { cryopreserved aliquots }\end{array}$ & $\begin{array}{l}\text { RPMl } 1640 \text { medium, penicillin- streptomycin, } \\
\text { amphotericin B, vancomycin, 20\% calf serum, } \\
\text { vitamins and non-essential amino acids as } \\
\text { described (Cushion et al., 2006) } \\
\text { PET track-etched membrane cell culture } \\
\text { inserts, Transwell, and Millicell-CM hydrophilic } \\
\text { (PTFE)\# membranes }\end{array}$ & $\begin{array}{l}\text { ATP content by } \\
\text { bioluminescence; } \\
\beta-1,3-\mathrm{D} \text {-glucan levels }\end{array}$ & $\begin{array}{l}\text { 8-10-fold; peak at Day } \\
10 \text { for } P \text {. carinii; not } \\
\text { reported for } P \text {. murina. } \\
61-75 \% \text { increase from } \\
\text { Day } 1 \text { to Day } 21 \text { for } \\
\text { both species }\end{array}$ \\
\hline
\end{tabular}

*No Growth.

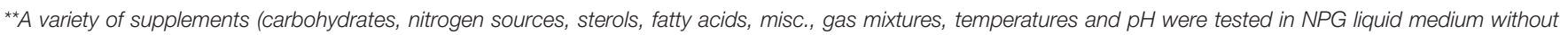
further improvement of growth (Cushion and Ebbets, 1990).

*** Larsen et al. (2002) found no organism replication using a quantitative touchdown PCR assay.

\#Best supported biofilm formation.

The biofilm cultures were then used to assess the effects of drugs on their ATP content. ATP measurement is used as a surrogate read out for viability (Cushion and Collins, 2011). These studies revealed several differences between the standard cell free suspension cultures and the biofilms. P. carinii organisms were more resistant to the echinocandins in mature biofilms than those in the RPMI 1640-based cell free suspension assay. Newly forming (nascent) biofilms were more susceptible than established biofilms and the populations in the nonadherent phase of the biofilms were generally more susceptible to echinocandin activity than the adherent populations. Notably, higher serum concentrations (10-20\%) abrogated the efficacy of the echinocandins, especially anidulafungin, in suspension or biofilm assay systems. Exposure to anidulafungin consistently and significantly reduced the ATP levels than did caspofungin or micafungin in either in vitro assay system. Though promising, the biofilm cultures failed to propagate outside the primary culture.

\section{WHAT ELEMENTS ARE MISSING FROM ALL THESE CULTIVATION EFFORTS?}

The systems summarized above and other unreported failures to identify an environment where these fungi can thrive, "begs the question-" what was lacking in these myriad of culture methods? With some exceptions, there has not been many systematic evaluations of media and supplements for Pneumocystis spp. growth. The standard approach of adding supplements in limited concentrations based on various rationales has not proven to be fruitful. Our laboratory embarked on a yearlong study supported by the United States National Institutes of Health, to systematically evaluate nutrients, trace metals, lipids, cofactors, and other compounds. We used an RPMI 1640-based cell free system with a $10-20 \%$ serum supplement, which seems to be indispensable for viability in our hands. In some cases, the rationale for supplements was based on a comparative genomics study that revealed the lack of ability to synthesize vital compounds, e.g., myo-inositol Porollo et al., 2014; Cushion et al., 2016), while others were more exploratory in nature, e.g., trace metals. Our experiences revealed a lack of batch-tobatch consistency from the cryopreserved Pneumocystis spp. we used. However, the addition of myo-inositol most consistently improved the ATP content vs the un-supplemented cultures.

Another apparent constancy from most of the studies was the peak of replication, growth, and viability early in primary culture after a few days in culture, with declining values thereafter. Such a clear signal suggests the following: (1) the small increases could be explained by a "coasting" of the Pneumocystis spp. life cycle stages, where some stages completed a replication or there is a spore release from asci using intracellular nutrients previously gleaned from the host environment; (2) the artificial media did not replenish critical nutrients or the concentrations were insufficient or at levels to be inhibitory to further growth; (3) there was no asci production, leading to a cessation of the life cycle; (4) the total environment cannot sustain replication, lacking a sufficient carbon dioxide level, support phase (liquid, gel, solid, e.g.), or substrate; (5) stimuli for asci production/sexual reproduction were absent. This last point is likely critical for a sustainable culture system, as we have shown recently that the sexual cycle is required for replication in rodent models of Pneumocystis infection (Cushion et al., 2010; Miesel et al., 2021).

Much of the life cycle of these fungi occurs in the mammalian lung and specifically in the alveoli. Within the alveoli, Pneumocystis preferentially and specifically attaches to the AEC1 cells which raises the question, why? Perhaps there are certain receptors on its surface that forms the tight interdigitation with these fungi. If so, what might be the purpose? Two thoughts come to mind that are not mutually exclusive. One is that there is an intimate exchange of nutrients that Pneumocystis requires. The second suggests a more cunning reason. By binding tightly to the very cell necessary for gas exchange, the fungal parasite directs a change in its immediate environment by altering the gas mixture, favoring a more hypoxic environment. There is some evidence that supports this hypothesis. The Pneumocystis genomes lack homologs to carbonic anhydrase genes (Ma et al., 2016). Carbonic anhydrases 


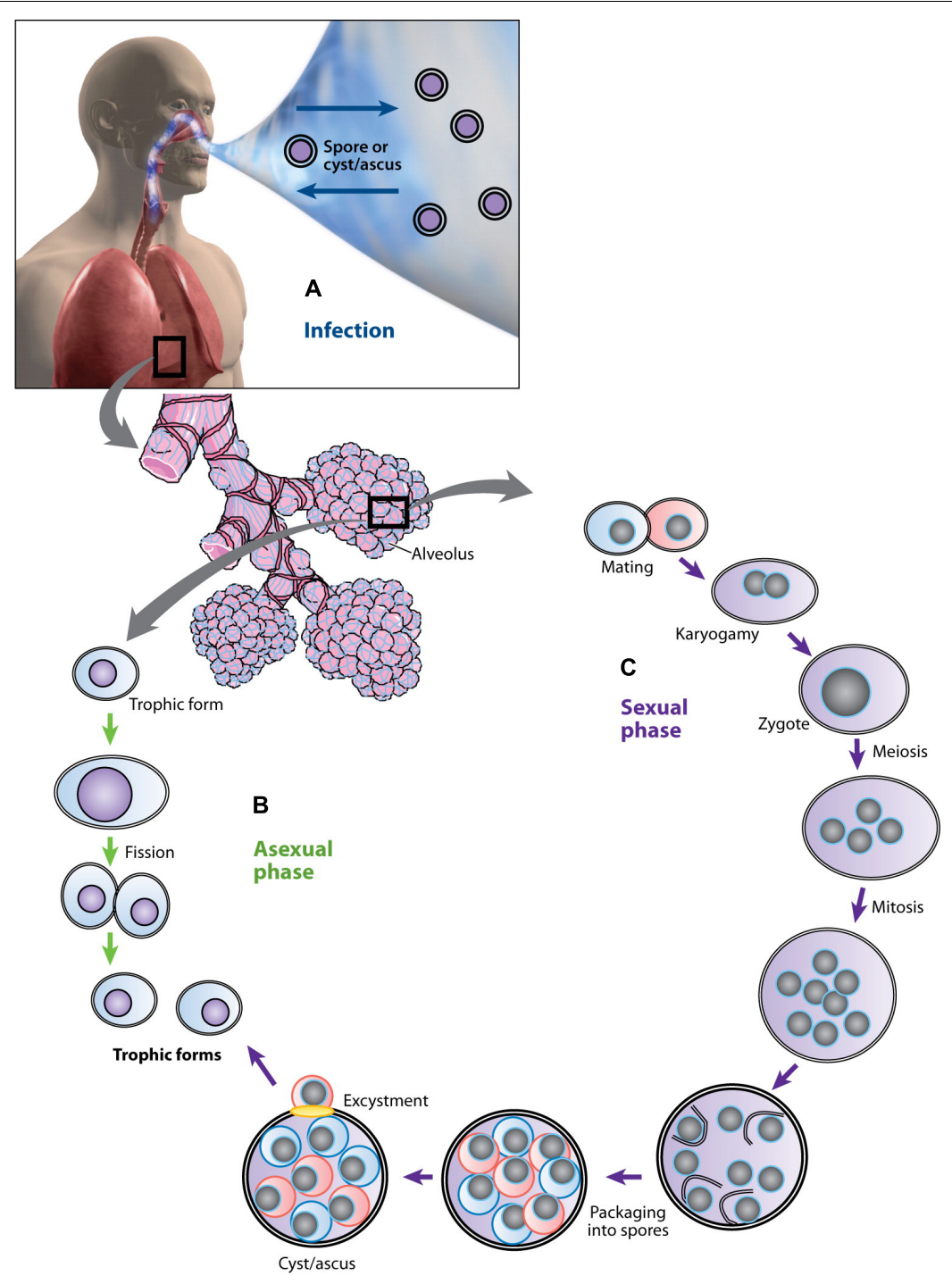

\section{A Cushion MT, Stringer JR. 2010.}

FIGURE 1 | Putative life cycle of Pneumocystis. (A) Infection. Recent studies suggest that the cyst/ascus (containing eight spores) is the agent of infection (inward arrow). After inhalation, the spores ultimately take residence in the terminal portion of the respiratory tree, the alveoli (enlarged bundles of alveoli shown in the illustration). Neither the mechanism of migration to the alveoli nor the form in which the organism arrives in the alveoli (intact ascus or individual spores) is known. It is speculated that the spores are released by exhalation (outward arrow). (B) Asexual phase. Haploid trophic forms are thought to replicate asexually by binary fission, a process whereby a single trophic form duplicates its genetic material and creates two daughter forms of roughly equal sizes. (C) Sexual phase. Two presumptive mating types conjugate, undergo karyogamy, and produce a diploid zygote that progresses through meiosis and then an additional mitosis to produce eight nuclei. The nuclei are packaged into spores by invagination of the ascus cell membranes. After completion, excystment occurs via a protunicate release by unknown mechanisms, which may involve a pore or opening in the cyst wall (yellow oval). The released spores become the vegetative forms, the haploid trophic forms, that can then undergo asexual or sexual replication (Images of man, alveoli purchased from Superstock Photos, http://www.superstock.com). Annual Reviews Authors: There is no need to obtain permission from Annual Reviews for the use of your own work(s). Our copyright transfer agreement provides you with all the necessary permissions. Our copyright transfer agreement provides: “... The nonexclusive right to use, reproduce, distribute, perform, update, create derivatives, and make copies of the work (electronically or in print) in connection with the author's teaching, conference presentations, lectures, and publications, provided proper attribution is given..."

catalyze the interconversion between carbon dioxide and water and the dissociation of carbonic acid, bicarbonate, and hydrogen ions. These enzymes maintain acid -base balance and helps to transport carbon dioxide. In the lungs, carbon dioxide is being released, so its concentration is lower than in tissue. The yeast genome contains a carbonic anhydrase encoded by NCE103 (Martin et al., 2017). The nce103 null mutant exhibits impaired growth under aerobic conditions, as do bacteria lacking these 


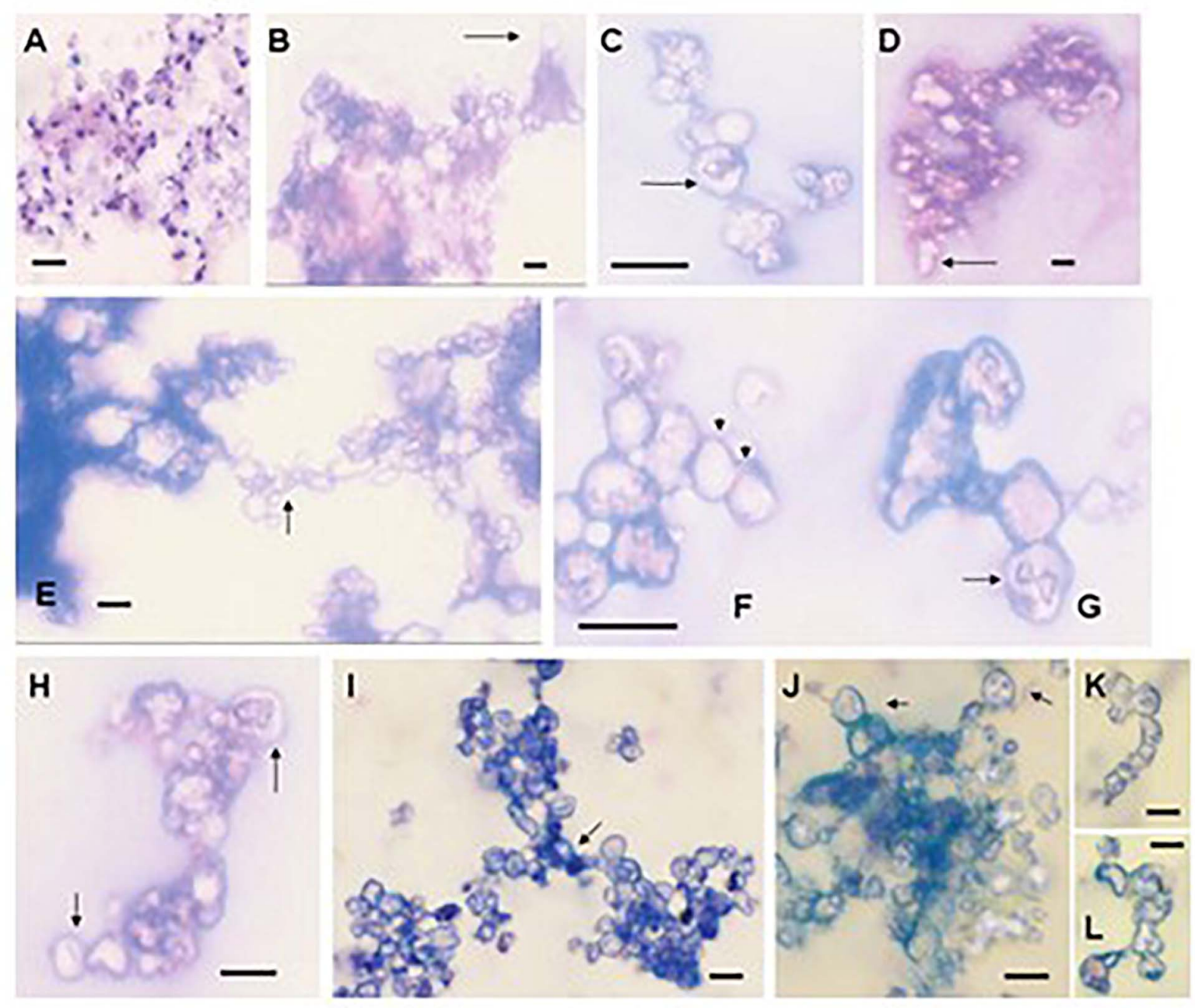

FIGURE 2 | The morphology of Pneumocystis changes dramatically during biofilm formation. (A) P. carinii from the supernatant of a 3-day-old standard short-term culture stained with Hema3, illustrating the differences in morphology from the biofilm structures. (B-H) Images were taken from 16-day-old biofilms inoculated with P. murina (obtained as a fresh isolate). The images were obtained from films on inserts that were scraped with a pipette tip, aspirated, air dried, and stained with Hema3, a rapid Wright-Giemsa stain. Images were viewed under oil immersion. Bars, 10 m. (B) P. murina cluster showing a cyst-like structure with a stalk (arrow). (C) An ascus in a chain with intracystic forms. (D) Refractile cluster beginning to form extensions (arrow). (E) Two large clusters forming a linkage or bridge structure (arrow). (F) A series of cyst-like structures forming a chain (arrows). (G) Cyst containing a structure which appears to be trophic forms undergoing binary fission or conjugation (arrow). (H) Ascus-like forms containing intracellular spore-like morphologies (arrows). (I-L) Images were taken from P. carinii biofilms at day 9 of the first passage. (I) Cluster mass seemingly comprised of three clusters that have joined in the center (arrow). (J) Ascus-like structures in a cluster with obvious intracellular contents resembling spores (arrows). (K,L) Chain-like forms. Bars, $10 \mu \mathrm{m}$ (Cushion et al., 2009).

enzymes However, growth under these conditions can be restored if augmented with high levels of carbon dioxide, which apparently satisfies the need for bicarbonate formation supplied by the carbonic anhydrases. Might these obligate fungal pathogens be facilitating their survival by increasing the carbon dioxide in their immediate environment? There is some evidence that this might occur. Our laboratory explored the effects of 3 different gas mixtures on the ATP content of $P$. carinii in an RPMI 1640based medium (Joffrion et al., 2006). A significant increase in ATP content was observed for fungi grown under microaerophilic conditions $(10-15 \%$ O2; 7-15\% CO2) when compared to standard conditions of 5\% CO2. Anaerobic conditions resulted in sharp decreases of ATP by $24 \mathrm{~h}$, suggesting that oxygen is required. Interestingly, these different atmospheres resulted in distinct responses to trimethoprim-sulfamethoxazole. Whereas the ATP levels of $P$. carinii in standard medium with 5\% CO2 had decreased levels of ATP by 75\% with treatment, those treated under microaerophilic conditions fell by only $50 \%$ vs the untreated controls. While the increase in carbon dioxide levels did not permit continuous culture, such a condition may play a key factor in future experiments with a more supportive culture structure. It should also be noted that the pulmonary epithelial 
pneumocytes do not have detectable carbonic anhydrases on their apical surface, accessible to the fluid lining, but activity is very abundant on the pulmonary endothelial cell surface facing the plasma (Effros, 2008). Thus, in such a bicarbonate starved environment, perhaps these fungi can find an alternative mode of acquisition.

The recent publications of the genomes of $P$. carinii, $P$. murina, and $P$. jirovecii identified metabolic cycles and pathways that are lacking in these fungi and are likely to lead to more rational supplementation studies (Cisse et al., 2014; Ma et al., 2016). Concomitant with such insights is the requirement for a balance of the supplement concentrations. Advances in metabolomics technology can suggest appropriate levels based on metabolic flux analyses while newer approaches to cell-based culture, e.g., air lift cultures, alveolar organoids, offer alternatives not available until recently. Lastly, a better understanding of the life cycle of these fungi and their apparent reliance on sexual reproduction strongly suggest that factors which stimulate this mode of replication needs to be considered in future in vitro culture systems. These considerations are discussed below.

\section{BIOTROPHY}

Several publications have revealed the host-obligate nature of Pneumocystis spp. (Cushion et al., 2007; Cisse et al., 2014; Hauser, 2014; Porollo et al., 2014; Ma et al., 2016). An early analysis of Expressed Sequence Tags (ESTs) from infected rat lungs demonstrated the absence of critical genes in such pathways as the pyruvate bypass and glyoxylate cycle, but the presence of genes necessary for carbohydrate metabolism, and suggested that Pneumocystis spp. may be obligate biotrophs (Cushion et al., 2007).

Biotrophy has been observed in fungi that invade plants, derive their energy from the host cells, but do not kill them. Obligate biotrophs complete their entire life cycle within the plant host, including the sexual cycle, and are incapable of growth outside the host (Lorrain et al., 2019). Pneumocystis spp. only grow within the lungs of mammals and complete their life cycle therein; are unable to grow outside the lungs (at present); and do not invade host cells. Pneumocystis do not produce hyphae in the lung and maintain an extracellular existence. Thus, Pneumocystis spp. fulfills these elements for biotrophic existence, including perhaps the lack of pathogenic effects. Though Pneumocystis spp. cause disease in immunocompromised hosts, it is currently held that mammals with intact immune systems are often transiently infected and may even enter a commensal lifestyle with the fungi without associated illness. It is only when the host tips the balance and losses its ability to control the infection that the organisms grow unchecked causing the disease state. It is also well known that Pneumocystis spp. grow slowly, even in severely immunocompromised hosts, suggesting they have adapted well to their hosts and are averse to killing them.

Another intriguing attribute of some obligate biotrophy in fungi such as plant pathogenic rust fungi is the network of intercellular hyphae called haustoria (Struck, 2015). Haustoria are structures considered to facilitate the acquisition of nutrients from the host cell. Haustoria form after the fungi penetrates the cell wall of the plant cell but do not wound the plant plasma membrane (Figure 3A). The haustoria grow in the living plant cells and are in intimate contact with the plant cell cytoplasm (Figure 3B). The cytoplasm of the host and fungus are separated by the host plasma membrane, the fungal plasma membrane and a matrix called the "extrahaustorial matrix" (Figures 3A,B). The species within the genus Pneumocystis are not known to produce hyphae, like many other fungi. Rather, they are relegated to the external mammalian lung environment. It is not difficult to imagine that the intimate interaction of the Pneumocystis trophic form with its alveolar host cell (Figure 1C) may be similar to that of the obligate biotrophic fungi with a structure that could conceivably facilitate nutrient acquisition. Early studies reported activation of the plasmalemmal vesicular system in the alveolar cells associated with trophic forms near the site of attachment to the AEC1 (Settnes and Nielsen, 1991), suggesting an approximation of a feeding complex. The trophic forms have long been considered the vegetative form of these fungi and this complex could be a novel manner of acquiring necessary nutrients lost during evolution of their parasitism.

\section{LOSS OF GENES IN METABOLIC PATHWAYS SUGGEST EXTENSIVE SUPPLEMENTS ARE NECESSARY}

Comparative genomic analyses do not suffer from problems associated with the analysis of the transcriptome, such as transient expression of genes involved in metabolic pathways. Using genomic analyses, Cisse et al. documented a dearth of enzymes necessary for amino acid synthesis in $P$. carinii (Cisse et al., 2014), with only 2 enzymes representing potential aspartic acid and glutamic acid synthesis as compared to Schizosaccharomyces pombe's 54 enzymes involved in amino acid biosynthesis. While our study also did not detect any gene homologs involved in isoleucine, leucine, lysine or valine biosynthesis, homologs for phenylalanine, tyrosine, and tryptophan biosynthesis were identified in all 3 species (Porollo et al., 2014). In addition, homologs for metabolism of glycine, serine, threonine, alanine, aspartate, glutamate, arginine, proline, histidine, tyrosine, phenylalanine, and tryptophan were detected as well as for valine, leucine, isoleucine, and lysine degradation. Counter-intuitive to the need for host amino acids, Ma et al. reported a dramatic reduction in amino acid permeases in the 3 sequenced genomes when compared to free-living and pathogenic fungi: 1 in each Pneumocystis genome vs 10 to 32 in the others (Ma et al., 2016). This finding could mean that the single permease in Pneumocystis is promiscuous or there are other means to import their amino acid requirements. In fact, $\mathrm{Ma}$ et al. notes that the number of transcription factors and transporters in Pneumocystis are among the lowest in fungi (Ma et al., 2016).

In a study which compared the genomes of $P$. jirovecii, $P$. murina and $P$. carinii with $S$. pombe, we noted the absence of inositol-1-phosphate synthase (INO1) and inositol monophosphatase (INM1) from all the Pneumocystis genomes 

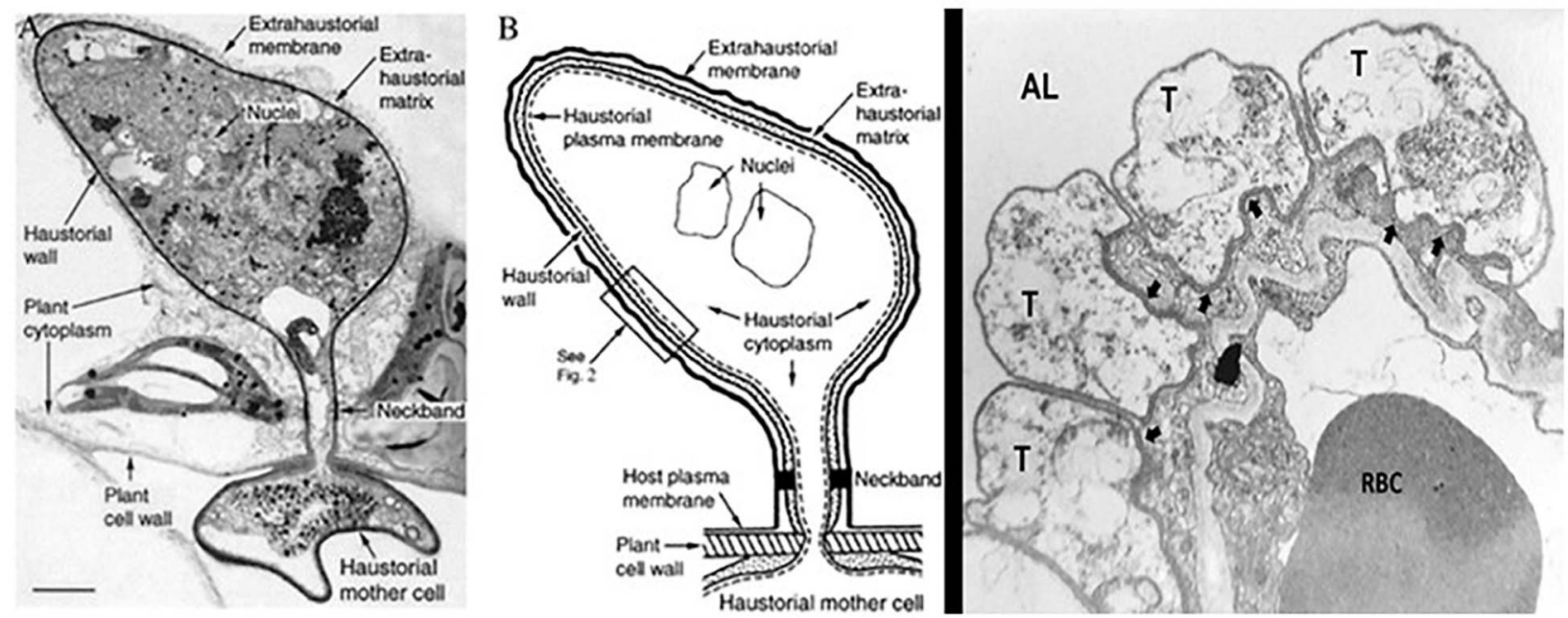

FIGURE 3 | Haustorial complex, a specialized feeding organ of biotrophic fungal parasites of plants. To move from host cell to fungus, nutrients must traverse the extrahaustorial membrane, the extrahaustorial matrix, the haustorial wall, and the haustorial plasma membrane. A neckband seals the extrahaustorial matrix from the plant cell wall region so that the matrix becomes a unique, isolated, apoplast-like compartment. The haustorium connects to intercellular fungal hyphae by way of a haustorial mother cell. A proton symport system in the haustorial plasma membrane drives sugar transport from plant to parasite. (A) Transmission electron micrograph of a flax rust haustorium [Reproduced with permission from ref. 2 (Copyright 1972, NRC Research Press)] (Bar, $1 \mu \mathrm{m}$ ). (B) Drawing showing key features of the fungal haustorium. (C) Electron micrograph of Pneumocystis trophic forms in tight apposition with the AEC1 in the lung alveoli. Trophic forms (T); Alveolar Lumen (AL); Red Blood Cell (RBC); arrows indicate the tight apposition of the trophic form double membrane with the AEC1 membranes. From the collection of MTC.

as well as from $S$. pombe (which had previously been reported) (Porollo et al., 2014). These genes encode the enzymes necessary for myo-inositol synthesis, a compound necessary for life in eukaryotes. This notable absence led us to the identification homologs to the $S$. pombe inositol transporter genes (ITR1 and ITR2) and the characterization of a highly specific myoinositol transporter in the genomes of all 3 species (ITR1) with a second homolog (ITR2) in the 2 rodent species (Porollo et al., 2014; Cushion et al., 2016). Notably, there were increased genes in inositol phosphate metabolism, starch and sucrose metabolism, and amino sugar and nucleotide sugar metabolism when compared to the genome of the free-living fission yeast. Also of interest was the 5 additional genes encoding enzymes in the tryptophan metabolism pathway in P. carinii and P. murina, which were absent in $P$. jirovecii (Porollo et al., 2014). To evaluate myo-inositol auxotrophy, supplementation studies of myo-inositol to both rodent species in a cell free in vitro system resulted in a notable increase in ATP and a longer period of viability (Porollo et al., 2014). Table 3 is a compilation of predicted nutritional supplements or conditions from published genomics studies.

\section{SEXUAL REPRODUCTION HOLDS THE KEY FOR IN VITRO REPLICATION}

Until recently it was assumed by most of the scientific community that like other fungi, Pneumocystis species could replicate asexually and sexually (Vossen et al., 1977; Vossen et al., 1978; Cushion, 2010; Skalski et al., 2015). Attempts to propagate these fungi in vitro typically led to apparent increases in the trophic form numbers and it was accepted that asexual replication was the preferred mode in these less-than-optimal culture systems. Other microbes like Giardia duodenalis, provided precedent in this thinking as only the trophozoites of these protozoans can be cultured in vitro (Perrucci et al., 2019) and those in the field settled with this shortcoming. With more current studies illustrating the reliance on the sexual cycle and asci formation as required for proliferation (Cushion et al., 2018), the absence of sexual replication in any in vitro system may be a key reason for lack of continuous growth. Notably, the use of a longacting echinocandin, rezafungin, as well as anidulafungin and caspofungin when given in a prophylactic model could prevent the infection (Miesel et al., 2021). Thus, we surmise that not only are these fungi dependent upon the host for the metabolic requirements they can no longer synthesize, but they must also undergo sexual replication to survive.

\section{INSIGHTS FOR FUTURE SUCCESS}

Thoughtful re-consideration of the previous attempts to propagate Pneumocystis species outside the mammalian lung environment indicates a clear role for a host cell component. Alveolar cells may offer an initial substrate for the newly released trophic forms from the asci or they may contribute directly to the nutrient pool via an intimate feeding structure as suggested above. Alternatively, secreted molecules from the alveolar cell encapsulated in extracellular vesicles or exported through simple exocytosis may also provide another source of required compounds. In our laboratory, we are exploring both two-dimensional and three-dimensional cellular based systems as 
TABLE 3 | Predicted nutritional supplements indicated by absent genes and pathways.

\begin{tabular}{|c|c|c|}
\hline References & Pneumocystis species & \\
\hline \multicolumn{3}{|c|}{ Amino Acids } \\
\hline \multirow[t]{18}{*}{ Hauser et al. (2010) } & P. carinii & Alanine \\
\hline & & Asparagine \\
\hline & & Arginine \\
\hline & & Cysteine \\
\hline & & Glutamine \\
\hline & & Glycine \\
\hline & & Histidine \\
\hline & & Isoleucine \\
\hline & & Leucine \\
\hline & & Lysine \\
\hline & & Methionine \\
\hline & & Phenylalanine \\
\hline & & Proline \\
\hline & & Serine \\
\hline & & Threonine \\
\hline & & Tryptophan \\
\hline & & Tyrosine \\
\hline & & Valine \\
\hline \multicolumn{3}{|c|}{ Vitamins } \\
\hline (Hauser, 2014) & $\begin{array}{l}\text { P. carinii, P. murina, } P . \\
\text { jirovecii }\end{array}$ & Thiamine (B1) \\
\hline Cushion MT & P. carinii, P. murina & Biotin $\left(\mathrm{H}, \mathrm{B}_{7}, \mathrm{~B}_{8}\right)$ \\
\hline \multicolumn{3}{|c|}{ Other } \\
\hline Porollo et al. (2014) & $\begin{array}{l}\text { P. carinii, P. murina, } P \text {. } \\
\text { jirovecii }\end{array}$ & $\begin{array}{l}\text { myo-inositol (carbocyclic } \\
\text { sugar) }\end{array}$ \\
\hline \multirow[t]{2}{*}{ (Hauser, 2014) } & $\begin{array}{l}P . \text { carinii, } P \text {. murina, } P \text {. } \\
\text { jirovecii }\end{array}$ & $\begin{array}{l}\text { Nitrogen and sulfur } \\
\text { assimilation }\end{array}$ \\
\hline & & Purine degradation \\
\hline Joffrion et al. (2006) & $\begin{array}{l}P . \text { carinii, } P \text {. murina, } P \text {. } \\
\text { jirovecii }\end{array}$ & $\begin{array}{l}\text { Increased carbon dioxide } \\
\text { atmosphere }\end{array}$ \\
\hline \multirow[t]{9}{*}{ Ma et al. (2016) } & $\begin{array}{l}\text { P. carinii, P. murina, } P \text {. } \\
\text { jirovecii }\end{array}$ & $\begin{array}{l}\text { Absence of polyamine } \\
\text { biosynthesis; evidence of a } \\
\text { polyamine transporter } \\
\text { suggests host acquisition }\end{array}$ \\
\hline & & Glucose \\
\hline & & Choline \\
\hline & & $\begin{array}{l}\text { Ether lipids, complex } \\
\text { sphingolipids, } \\
\text { phosphatidylinositol, } \\
\text { phosphatidylcholine, fatty } \\
\text { acids }\end{array}$ \\
\hline & & Glycerol \\
\hline & & Pantothenate \\
\hline & & Ubiquinone/coenzyme Q \\
\hline & & Siderophores \\
\hline & P. jirovecii only & $\begin{array}{l}\text { Nicotinamide adenine } \\
\text { dinucleotide }\end{array}$ \\
\hline Ma et al. (2016) & $\begin{array}{l}\text { P. carinii, } P \text {. murina (but not } \\
P . \text { jirovecii) }\end{array}$ & Cholesterol \\
\hline Furlong et al. (1997) & P. carinii & Fatty acids, cholesterol \\
\hline Worsham et al. & P. carinii & Cholesterol \\
\hline
\end{tabular}

potential growth systems. We provide some preliminary results and discussions below.

\section{THREE-DIMENSIONAL ALVEOLAR ORGANOIDS}

Methodology for the routine culture of enteric organoids is now quite advanced, but alveolar organoids remain a challenge ( $\mathrm{Li}$ et al., 2020). Our laboratory explored a mouse lung cell organoid approach for anticipated inoculation of $P$. murina, the species that infects the mouse. This reasoning was based on evidence of species specificity of Pneumocystis for its mammalian hosts, e.g., $P$. carinii only infects rats, $P$. murina only infects mice. Results were promising and will be published in a separate report.

\section{AIR-LIQUID INTERFACE CELL CULTURES}

Air liquid interface (ALI) cultures are used for respiratory research. Both primary cells from donors and immortalized cell lines have been used. The ALI system is defined by contact of the basal surface of the cells with liquid culture medium while the apical surface is exposed to air. Such a juxtaposition permits differentiation, as in the case of human bronchial epithelial cells transitioning to a pseudostratified mucociliary phenotype. To initiate the cultures, cells are typically placed onto a permeable membrane of a cell culture insert with medium within the insert and in the cell well below. Once confluent, the medium is only provided to the basal chamber, causing the "air lift" of the cells in the insert. Indeed, Schildgen et al. used such an ALI system with human airway cells, $\mathrm{CuFi}-8$, which were derived from the bronchus of a patient with cystic fibrosis (Schildgen et al., 2014). As in previous attempts, $P$. jirovecii could not be continuously cultured in this system and in this case, it may have been due to the type of cell used for the ALI, bronchus derived cells rather than alveolar epithelial cell.

Our laboratory used this approach with the A549 cell line (ATCC CCL 185) which is described as an adenocarcinomic human alveolar basal epithelial cell derived from cancerous lung tissue of a 58-year-old Caucasian male (Giard et al., 1973). After air lift, the cultures were inoculated with $P$. murina, since the species infecting humans, $P$. jirovecii is not widely available. There was not a high expectation for growth, but this was rather an observational exercise. Somewhat surprisingly, the A549 cultures produced AEC1-like cells that stained with podoplanin, a marker for this cell type, and not with Surfactant Protein B, a marker for AEC2 cells. Staining with a marker specific for P. murina, the Major Surface Glycoprotein (Msg) superfamily of surface antigens, we could show that the fungi were attached to the apical surface and to the AEC1 cells. An optimal ALI would use host cells from the natural host wherein the Pneumocystis species reside. This approach demands more investigation as a potential growth system. 


\section{Alveolar Lung Chips}

Significant advancements in lung-chip models also offer promise. Such systems are commercially available and offer support platforms for epithelial and vascular channels, cell-cell interactions, immune cells, extracellular matrix and mechanical forces (Benam et al., 2016). Importantly for the potential growth of Pneumocystis spp., alveolar epithelial cells (AEC) can maintain AEC1 and AEC2 cell structure with expression of specific markers. Such systems can be used to evaluate drug response and inflammatory responses and may even be able to provide insights into factors responsible for species specificity. One drawback is that these systems are currently limited in their life span, which is about 2 weeks.

\section{METABOLOMICS}

Metabolomics is a growing field that enables the unbiased detection and measurement of metabolites resulting from cell metabolism. Commonly, NMR spectroscopy is used to build profiles of the physiology of cells at the time of sampling. Application of this technology to identify and assess the utilization of host products by Pneumocystis in cell culture or even in vivo should provide additional detailed information related to cell cycle requirements of these obligate fungi. Our lab used H-NMR spectroscopy to assess the dynamics of uptake and secretion of metabolites by $P$. murina within the extracellular medium. We learned that there were notable differences in the metabolite profiles between organisms that were isolated from the rodent lungs and used immediately afterwards and those that had undergone cryopreservation and subsequently thawed and reconstituted. We gathered that the source of organisms needs to be accounted for in future culture supplementation attempts. The freshly isolated organisms completely depleted glucose available in the media by day 3 , whereas cryopreserved fungi had glucose levels comparable to the day of inoculation into the medium. The metabolic byproduct acetate accumulated in greater concentrations and more rapidly in cultures inoculated with the freshly isolated P. murina vs the cryopreserved fungi. Such information can be used to direct choices of culture supplements, supplement concentrations, and regimens for refeeding.

\section{REFERENCES}

Aliouat el, M., Dujardin, L., Martinez, A., Duriez, T., Ricard, I., and Dei-Cas, E. (1999). Pneumocystis carinii growth kinetics in culture systems and in hosts: involvement of each life cycle parasite stage. J. Eukaryot. Microbiol. 46, 116S-117S.

Atzori, C., Aliouat, E. M., Bartlett, M. S., Dujardin, L., Cargnel, A., and Dei-Cas, E. (1998). Current in vitro culture systems for Pneumocystis. FEMS Immunol. Med. Microbiol. 22, 169-172.

Bartlett, M. S., Edlind, T. D., Durkin, M. M., Shaw, M. M., Queener, S. F., and Smith, J. W. (1992). Antimicrotubule benzimidazoles inhibit in vitro growth of Pneumocystis carinii. Antimicrob. Agents Chemother. 36, 779-782. doi: 10.1128/ aac.36.4.779

Bartlett, M. S., Verbanac, P. A., and Smith, J. W. (1979). Cultivation of Pneumocystis carinii with WI-38 cells. J. Clin. Microbiol. 10, 796-799. doi: $10.1128 / \mathrm{jcm} \cdot 10.6 .796-799.1979$

\section{DISCUSSION}

The establishment of a continuous cultivation system for Pneumocystis spp. may lie in our grasp though many parameters must be considered prior to embarking on this ambitious goal. Systematic evaluations that titrate concentrations of appropriate supplements will be necessary. Metabolomics and metabolic flux analyses can be used to guide the amounts and timing of additives. Serious consideration must be given to cellular or other support matrices. Alveolar organoid for studies of pathology and perhaps growth, as well as Air Liquid Interface (ALI) cultures, are exciting avenues that should be explored. Recent genomic, animal model, and transcriptomic studies clearly reveal a requirement for sexual reproduction resulting in the formation of asci for survival of these fungi. Stimulation of the sexual cycle will be paramount in determining a successful culture milieu.

\section{AUTHOR CONTRIBUTIONS}

MC, NT, SS, and AP contributed to conception and design of the study. NT and SS performed and wrote the ALI and organoid sections. AP conceived and analyzed the metabolomics data. All authors performed the statistical analysis. MC wrote the first and final draft of the manuscript. NT, SS, and AP wrote sections of the manuscript. All authors contributed to manuscript revision, read, and approved the submitted version.

\section{FUNDING}

This work utilized funding from the NIAID R01HL46266 and NIH Contract No. HHSN2722011000181. Task Order HHSN27200010. A22. Development of a New System for Scaled up Culture and Propagation of Pneumocystis. NIH/NHLBI. MC is supported in part by a Biomedical Laboratory Research and Development Senior Research Career Scientist Award from the United States Department of Veterans Affairs (award number IK6BX005232).

Benam, K. H., Villenave, R., Lucchesi, C., Varone, A., Hubeau, C., Lee, H.-H., et al. (2016). Small airway-on-a-chip enables analysis of human lung inflammation and drug responses in vitro. Nat. Methods 13, 151-157.

Cirioni, O., Giacometti, A., Barchiesi, F., and Scalise, G. (2000). Inhibition of growth of Pneumocystis carinii by lactoferrins alone and in combination with pyrimethamine, clarithromycin and minocycline. J. Antimicrob. Chemother. 46, 577-582. doi: 10.1093/jac/46.4.577

Cirioni, O., Giacometti, A., Quarta, M., and Scalise, G. (1997). In-vitro activity of topoisomerase inhibitors against Pneumocystis carinii. J. Antimicrob. Chemother. 40, 583-586. doi: 10.1093/jac/40.4.583

Cisse, O. H., Pagni, M., and Hauser, P. M. (2014). Comparative genomics suggests that the human pathogenic fungus Pneumocystis jirovecii acquired obligate biotrophy through gene loss. Genome Biol. Evol. 6, 1938-1948. doi: 10.1093/ gbe/evu155

Cushion, M. T. (1989). In vitro studies of Pneumocystis carinii. J. Protozool. 36, 45-52. 
Cushion, M. T. (2010). Are members of the fungal genus pneumocystis (a) commensals; (b) opportunists; (c) pathogens; or (d) all of the above? PLoS.Pathog. 6:e1001009. doi: 10.1371/journal.ppat.1001009

Cushion, M. T., and Collins, M. S. (2011). Susceptibility of Pneumocystis to echinocandins in suspension and biofilm cultures. Antimicrob. Agents Chemother. 55, 4513-4518. doi: 10.1128/aac.00017-11

Cushion, M. T., and Ebbets, D. (1990). Growth and metabolism of Pneumocystis carinii in axenic culture. J. Clin. Microbiol. 28, 1385-1394. doi: 10.1128/jcm.28. $6.1385-1394.1990$

Cushion, M. T., and Walzer, P. D. (1984). Growth and serial passage of Pneumocystis carinii in the A549 cell line. Infect. Immun. 44, 245-251. doi: 10.1128/iai.44.2.245-251.1984

Cushion, M. T., Ashbaugh, A., Hendrix, K., Linke, M. J., Tisdale, N., Sayson, S. G., et al. (2018). Gene expression of Pneumocystis murina after treatment with Anidulafungin results in strong signals for sexual reproduction, cell wall integrity, and cell cycle arrest, indicating a requirement for ascus formation for proliferation. Antimicrob. Agents Chemother. 62, e2513-e2517.

Cushion, M. T., Collins, M. S., and Linke, M. J. (2009). Biofilm formation by Pneumocystis spp. Eukaryot Cell 8, 197-206. doi: 10.1128/ec.00202-08

Cushion, M. T., Collins, M. S., Sesterhenn, T., Porollo, A., Vadukoot, A. K., and Merino, E. J. (2016). Functional characterization of pneumocystis carinii inositol transporter 1. mBio 7:e1851-16.

Cushion, M. T., Keely, S. P., and Stringer, J. R. (2004). Molecular and phenotypic description of Pneumocystis wakefieldiae sp. nov., a new species in rats. Mycologia 96, 429-438. doi: 10.2307/3762163

Cushion, M. T., Linke, M. J., Ashbaugh, A., Sesterhenn, T., Collins, M. S., Lynch, K., et al. (2010). Echinocandin treatment of pneumocystis pneumonia in rodent models depletes cysts leaving trophic burdens that cannot transmit the infection. PLoS One 5:e8524. doi: 10.1371/journal.pone.0008524

Cushion, M. T., Ruffolo, J. J., Linke, M. J., and Walzer, P. D. (1985). Pneumocystis carinii: growth variables and estimates in the A549 and WI-38 VA13 human cell lines. Exp. Parasitol. 60, 43-54. doi: 10.1016/s0014-4894(85)80021-7

Cushion, M. T., Smulian, A. G., Slaven, B. E., Sesterhenn, T., Arnold, J., Staben, C., et al. (2007). Transcriptome of Pneumocystis carinii during fulminate infection: carbohydrate metabolism and the concept of a compatible parasite. PLoS.One. 2:e423. doi: 10.1371/journal.pone.0000423

Cushion, M. T., Walzer, P. D., Ashbaugh, A., Rebholz, S., Brubaker, R., Vanden Eynde, J. J., et al. (2006). In vitro selection and in vivo efficacy of piperazineand alkanediamide-linked bisbenzamidines against Pneumocystis pneumonia in mice. Antimicrob. Agents Chemother. 50, 2337-2343. doi: 10.1128/aac. 00126-06

Dei-Cas, E., Chabe, M., Moukhlis, R., Durand-Joly, I., Aliouat el, M., Stringer, J. R., et al. (2006). Pneumocystis oryctolagi sp. nov., an uncultured fungus causing pneumonia in rabbits at weaning: review of current knowledge, and description of a new taxon on genotypic, phylogenetic and phenotypic bases. FEMS Microbiol, Rev. 30, 853-871. doi: 10.1111/j.1574-6976.2006.00037.x

Effros, R. M. (2008). Carbonic anhydrase and alveolar fluid absorption. Am. J. Respir. Cell. Mol. Biol. 39, 124-125. doi: 10.1165/ajrcmb.39.1.124a

Fehrenbach, H. (2001). Alveolar epithelial type II cell: defender of the alveolus revisited. Respiratory Res. 2, 33-46.

Furlong, S. T., Koziel, H., Bartlett, M. S., McLaughlin, G. L., Shaw, M. M., and Jack, R. M. (1997). Lipid transfer from human epithelial cells to Pneumocystis carinii in vitro. J. Infect. Dis. 175, 661-668. doi: 10.1093/infdis/175.3.661

Giard, D. J., Aaronson, S. A., Todaro, G. J., Arnstein, P., Kersey, J. H., Dosik, H., et al. (1973). In vitro cultivation of human tumors: establishment of cell lines derived from a series of solid tumors. J. Natl. Cancer Inst. 51, 1417-1423. doi: 10.1093/jnci/51.5.1417

Hauser, P. M. (2014). Genomic insights into the fungal pathogens of the genus pneumocystis: obligate biotrophs of humans and other mammals. PLoS Pathog 10:e1004425. doi: 10.1371/journal.ppat.1004425

Hauser, P. M., and Cushion, M. T. (2018). Is sex necessary for the proliferation and transmission of Pneumocystis? PLoS Pathogens 14:e1007409. doi: 10.1371/ journal.ppat.1007409

Hauser, P. M., Burdet, F. X., Cisse, O. H., Keller, L., Taffe, P., Sanglard, D., et al. (2010). Comparative genomics suggests that the fungal pathogen pneumocystis is an obligate parasite scavenging amino acids from its host's lungs. PLoS.One. 5:e15152. doi: 10.1371/journal.pone.0015152
Joffrion, T. M., Collins, M. S., and Cushion, M. T. (2006). Microaerophilic conditions increase viability and affect responses of Pneumocystis carinii to drugs in vitro. J. Eukaryot Microbiol. 53 (Suppl. 1):S117-8.

Kanj, A., Samhouri, B., Abdallah, N., Chehab, O., and Baqir, M. (2021). Host factors and outcomes in hospitalizations for Pneumocystis Jirovecii Pneumonia in the United States. Mayo. Clin. Proc. 96, 400-407. doi: 10.1016/j.mayocp.2020.07. 029

Keely, S. P., Fischer, J. M., Cushion, M. T., and Stringer, J. R. (2004). Phylogenetic identification of Pneumocystis murina sp. nov., a new species in laboratory mice. Microbiology (Reading) 150, 1153-1165. doi: 10.1099/mic.0.26921-0

Knudsen, L., and Ochs, M. (2018). The micromechanics of lung alveoli: structure and function of surfactant and tissue components. Histochem. Cell. Biol. 150, 661-676. doi: 10.1007/s00418-018-1747-9

Larsen, H. H., Kovacs, J. A., Stock, F., Vestereng, V. H., Lundgren, B., Fischer, S. H., et al. (2002). Development of a rapid real-time PCR assay for quantitation of Pneumocystis carinii f. sp. carinii. J. Clin. Microbiol. 40, 2989-2993. doi: 10.1128/jcm.40.8.2989-2993.2002

Lasbury, M. E., Goheen, M. P., Durant, P. J., Bartlett, M. S., Smith, J. W., and Lee, C. H. (1999). Mouse derived Pneumocystis carinii in an axenic culture system. J. Eukaryot. Microbiol. 46, 120S-121S.

Latorre, C. R., Sulzer, A. J., and Norman, L. G. (1977). Serial propagation of Pneumocystis carinii in cell line cultures. Appl. Environ. Microbiol. 33, 12041206. doi: $10.1128 / \mathrm{aem} .33 .5 .1204-1206.1977$

Li, Y., Wu, Q., Sun, X., Shen, J., and Chen, H. (2020). Organoids as a powerful model for respiratory diseases. Stem. Cells Int. 2020:5847876.

Liu, Y., Fahle, G. A., and Kovacs, J. A. (2018). Inability to culture \&lt;span class=\&quot;named-content genus-species\&quot; id=\&quot;named-content1\&quot;\&gt;Pneumocystis jirovecii\&it;/span\&gt. mBio 9:e939-18.

Lorrain, C., Gonçalves dos Santos, K. C., Germain, H., Hecker, A., and Duplessis, S. (2019). Advances in understanding obligate biotrophy in rust fungi. New Phytol. 222, 1190-1206. doi: 10.1111/nph.15641

Ma, L., Chen, Z., Huang da, W., Kutty, G., Ishihara, M., Wang, H., et al. (2016). Genome analysis of three Pneumocystis species reveals adaptation mechanisms to life exclusively in mammalian hosts. Nat. Commun. 7:10740.

Martin, R., Pohlers, S., Mühlschlegel, F. A., and Kurzai, O. (2017). CO(2) sensing in fungi: at the heart of metabolic signaling. Curr. Genet. 63, 965-972. doi: 10.1007/s00294-017-0700-0

Martinez, L. R., and Casadevall, A. (2007). Cryptococcus neoformans biofilm formation depends on surface support and carbon source and reduces fungal cell susceptibility to heat, cold, and UV light. Appl. Environ. Microbiol. 73, 4592-4601. doi: 10.1128/aem.02506-06

Merali, S., Frevert, U., Williams, J. H., Chin, K., Bryan, R., and Clarkson, A. B. Jr. (1999). Continuous axenic cultivation of Pneumocystis carinii. Proc. Natl. Acad. Sci. U.S.A. 96, 2402-2407. doi: 10.1073/pnas. 96.5 .2402

Miesel, L., Cushion, M. T., Ashbaugh, A., Lopez, S. R., and Ong, V. (2021). Efficacy of rezafungin in prophylactic mouse models of invasive candidiasis, aspergillosis, and pneumocystis pneumonia. Antimicrob. Agents Chemother. 65:e1992-20.

Mowat, E., Butcher, J., Lang, S., Williams, C., and Ramage, G. (2007). Development of a simple model for studying the effects of antifungal agents on multicellular communities of Aspergillus fumigatus. J. Med. Microbiol. 56, 1205-1212. doi: $10.1099 / \mathrm{jmm} .0 .47247-0$

$\mathrm{Ni}, \mathrm{X}$., and Chen, Y. (2001). [In vitro study of the anti-pneumocystis carinii effect of arteminsin derivatives]. Zhonghua Jie. He. He. Hu Xi. Za Zhi. 24, 164-167.

Perrucci, S., Fichi, G., Ricci, E., Galosi, L., Lalle, M., and Rossi, G. (2019). In vitro and ex vivo evaluation of the anti-Giardia duodenalis activity of the supernatant of Slab51 (SivoMixx). PLoS One 14:e0213385. doi: 10.1371/journal. pone. 0213385

Pifer, L. L., Hughes, W. T., and Murphy, M. J. Jr. (1977). Propagation of Pneumocystis carinii in vitro. Pediatr. Res. 11, 305-316. doi: 10.1203/00006450197704000-00010

Pifer, L. L., Woods, D., and Hughes, W. T. (1978). Propagation of Pneumocystis carinii in Vero cell culture. Infect. Immun. 20, 66-68. doi: 10.1128/iai.20.1.6668.1978

Porollo, A., Sesterhenn, T. M., Collins, M. S., Welge, J. A., and Cushion, M. T. (2014). Comparative genomics of pneumocystis species suggests the absence of genes for myo-inositol synthesis and reliance on inositol transport and metabolism. mBio 5:e01834. 
Ramage, G., Vande Walle, K., Wickes, B. L., and ópez-Ribot, J. L. L. (2001a). Biofilm formation by Candida dubliniensis. J. Clin. Microbiol. 39, 3234-3240. doi: $10.1128 /$ jcm.39.9.3234-3240.2001

Ramage, G., Wickes, B. L., and Lopez-Ribot, J. L. (2001b). Biofilms of Candida albicans and their associated resistance to antifungal agents. Am. Clin. Lab. 20, 42-44.

Redhead, S. A., Cushion, M. T., Frenkel, J. K., and Stringer, J. R. (2006). Pneumocystis and Trypanosoma cruzi: nomenclature and typifications. J. Eukaryot. Microbiol. 53, 2-11. doi: 10.1111/j.1550-7408.2005.00072.x

Schildgen, V., Mai, S., Khalfaoui, S., Lusebrink, J., Pieper, M., Tillmann, R. L., et al. (2014). Pneumocystis jirovecii can be productively cultured in differentiated CuFi-8 airway cells. $m$ Bio 5:e1186-14.

Settnes, O. P., and Nielsen, M. J. (1991). Host-parasite relationship in Pneumocystis carinii infection: activation of the plasmalemmal vesicular system in type I alveolar epithelial cells. J. Protozool. 38, 174S-176S.

Skalski, J. H., Kottom, T. J., and Limper, A. H. (2015). Pathobiology of Pneumocystis pneumonia: life cycle, cell wall and cell signal transduction. FEMS Yeast Res. 15:fov046. doi: 10.1093/femsyr/fov046

Smith, J. W., and Bartlett, M. S. (1984). "In vitro cultivation of Pneumocystis," in Pneumocystis carinii Pneumonia, ed. L. Young (New York, N Y: Marcel Dekker, Inc), 107-137.

Sobolewska, A., and Dzbenski, T. H. (2009). In vitro cultivation of Pneumocystis isolated from infected rat lungs. Wiad. Parazytol. 55, 451-457.

Struck, C. (2015). Amino acid uptake in rust fungi. Front. Plant Sci. 6:40. doi: $10.3389 /$ fpls. 2015.00040
The Pneumonia Etiology Research for Child Health (Perch) study group (2019). Causes of severe pneumonia requiring hospital admission in children without HIV infection from Africa and Asia: the PERCH multi-country case-control study. Lancet 394, 757-779.

Vossen, M. E., Beckers, P. J., Meuwissen, J. H., and Stadhouders, A. M. (1978). Developmental biology of Pneumocystis carinii, and alternative view on the life cycle of the parasite. Z. Parasitenkd. 55, 101-118. doi: 10.1007/bf00384826

Vossen, M. E., Beckers, P. J., Stadhouders, A. M., Bergers, A. M., and Meuwissen, J. H. (1977). New aspects of the life cycle of Pneumocystis carinii. Z. Parasitenkd. 51, 213-217. doi: 10.1007/bf00500960

Worsham, D. N., Basselin, M., Smulian, A. G., Beach, D. H., and Kaneshiro, E. S. (2003). Evidence for cholesterol scavenging by Pneumocystis and potential modifications of host-synthesized sterols by the P. carinii SAM:SMT. J. Eukaryot. Microbiol. 50, 678-679. doi: 10.1111/j.1550-7408.2003.tb00683.x

Conflict of Interest: The authors declare that the research was conducted in the absence of any commercial or financial relationships that could be construed as a potential conflict of interest.

Copyright (c) 2021 Cushion, Tisdale-Macioce, Sayson and Porollo. This is an openaccess article distributed under the terms of the Creative Commons Attribution License (CC BY). The use, distribution or reproduction in other forums is permitted, provided the original author(s) and the copyright owner(s) are credited and that the original publication in this journal is cited, in accordance with accepted academic practice. No use, distribution or reproduction is permitted which does not comply with these terms. 